\title{
ESSAI
}

Volume 10

Article 9

4-1-2012

\section{Prejudice and Acceptance}

Lynn Altman

College of DuPage

Follow this and additional works at: http://dc.cod.edu/essai

\section{Recommended Citation}

Altman, Lynn (2013) "Prejudice and Acceptance," ESSAI: Vol. 10, Article 9.

Available at: http://dc.cod.edu/essai/vol10/iss1/9

This Selection is brought to you for free and open access by the College Publications at DigitalCommons@C.O.D.. It has been accepted for inclusion in ESSAI by an authorized administrator of DigitalCommons@C.O.D.. For more information, please contact koteles@cod.edu. 
Prejudice and Acceptance

by Lynn Altman

(English 1102)

$\mathrm{P}$ rejudice is still present in society today and I think people are not doing enough to eliminate it. What is prejudice? Prejudice is bias; an opinion held in disregard of facts that contradict it (Webster's New World Dictionary and Thesaurus, Second Ed.). The most common excuses for prejudice are sex, race, age, religion, sexual orientation, and education. Why are people prejudiced towards one another? I believe it's primarily because we are a stubborn race and do not want to understand our differences. I think prejudice leads to tragedy, as seen in the short stories "Désirée's Baby," "In Response to Executive Order 9066," and "The Bridegroom."

"Désirée's Baby" is a love story in which a marriage is destroyed by racial prejudice. It begins with a young couple, the Valmondés, adopting a child, Désirée, of unknown origin. This child grows into a beautiful young woman and becomes the object of the neighbor's affection. The neighbor, Armand Aubigny, is a young man that comes from a wealthy family with a strong name. After starting a family, Armand falls out of love with Désirée because he believes she has brought injury to his home and name by having a child that is not white. When he rejects his wife and child, she leaves his home and takes her life and the life of their child.

Reading "Désirée's Baby" the first time, I could feel the prejudice against the characters that were not white. It was said that Armand was strict with his slaves, often yelling and treating them unkindly at his home, L'Abri. When Madame Valmondé visits L'Abri, she shudders because it was "a sad looking place" (242). When Armand falls in love with Désirée, Monsieur Valmondé tries to be practical. He "wanted things well considered; that is, the girl's obscure origin" (242). "Armand looked into her eyes and did not care" (242). This was a lie, as seen by his reaction to Désirée and their child. Soon after his son was born, the child began to take on the color of a quadroon child, a quarter black. Armand could not overcome his feelings of betrayal. As noted by DizzyRae, "Armand's pride was bigger and more than the love for his wife" (1). We are reminded by Dr. Mark, that the belief during this time was that "a person with one drop of African blood be considered wholly black" (2).

But racial prejudice is not the only prejudice in the story. The less obvious one is the prejudice against women, as noted by Joseph Rosenblum, "The characters' world is also one in which women, like blacks, are second-class citizens" (3). When I reread the story, Rosenblum's observation was most easily seen when Désirée left. What choice did Désirée have? Her reaction of killing herself and child at first seemed severe, but moving back to her adopted mother, they would have lived forever as outcasts. As a single woman with a quadroon child, she would not be accepted as an equal.

At the end of the story, Armand has a great bonfire. Armand was burning everything of Désirée's and the baby's, as if he wanted no reminders of their existence. I believe he is beginning to regret his actions and wants to rid himself of the reminders of what he had and lost. After he condemned Désirée and their child, he found a letter from his mother that revealed that he, not Désirée, was the reason the child was not white.

Monsieur and Madame Valmondé are great role models. They open their home to Désirée as a child and soon adopt her. Madame Valmondé suspects something is different with the baby during her visit. She took the child to the "window that was lightest and scanned the baby narrowly" (243). She admits that the child "has changed" (243) but does not voice her suspicions. When Désirée 
writes to her of Armand's rejection, Madame tells Désirée to return to Valmondé with the child where they will be loved. Unfortunately for all, Désirée had spoken the truth to her mother in her letter. "I shall die. I must die. I cannot be so unhappy and live" (244).

In order to stop prejudice, parents need to be conscious of what they teach their children. The innocence of a child and their ready acceptance of their parents' views are easily seen in "In Response to Order 9066, All Americans of Japanese Descent Must Report to Relocation Centers." Okida wrote the poem from a young girl's point of view. He modeled it after his mother, who had lived through this injustice.

The poem begins with the young girl happily preparing her things for camp. She is explaining to us what she will bring. The parents do not explain it's a detention camp, not one filled with games and singing. I think the parents did this for two reasons. The first reason is so the child will not worry excessively. The child is going to be scared and nervous, but having the child prepare for camp as an experience she may look forward to helps keep an open mind. The second reason is to avoid teaching the child prejudice. The child is not going to start her stay at the camp with dislike in her heart but is going to try to plant her tomato seeds, "love apples" (695), instead.

The girl's parents have explained they are going to this camp because they are JapaneseAmerican. In this letter to the government, the girl tries to explain how she is just like the American girls her age. She has a white best friend, a messy room, looks at boys, loves hot dogs, and feels funny using chopsticks. As Constantakis notes, "She gives the official this information in the hope that it will make a difference as to whether she is going to be considered an American or a Japanese person" (2).

It is doubtful her letter will make a difference to the government, but sadder still is that overnight her best friend, Denise, has turned against her. At school the next day, Denise is on the other side of the room and blaming the author for causing the war. "Your trying to start a war, she said, giving secrets away to the enemy. Why can't you keep your big mouth shut?" I agree with Positivelydifferent that Denise "was probably told by an adult about the American vs. Japanese matters, and mistreats the girl for this" (1). Why else would Denise feel so strongly about the girl's nationality?

The shock of losing her best friend left the girl speechless. I don't think it deflated her dreams because she gave a packet of tomato seeds to Denise and asked her to plant them. I think this symbolizes the author's hopes. The seeds with love and care can blossom into something fruitful and beautiful. It will hopefully help Denise learn not to judge too quickly as she will need patience to grow the plants. They grow at their own pace, not the gardener's.

I chose this poem to illustrate how wrong it is to teach our children our prejudices. Children should be allowed to grow up and make friends with whomever they choose, not because they were told you can't have that person for your friend. I think we have moved a little in the right direction, but not far enough. After 911, we didn't have relocation camps, but other injustices were done because of nationality or religious beliefs. I heard it from some of the children in the schools. They had obviously heard these things from their parents because they could not explain why they felt the way they did.

It is sad how little progress we have made. We must work harder at teaching our kids to be positives, not to perceive negatives.

My final example of how prejudice leads to tragedy is in the story "The Bridegroom" by Ha Jin. A family is torn apart by homosexuality because it is not understood and therefore they have no tolerance for it. Sexual preference is not as easily identified as some of the other prejudices, like race or nationality, but it is a problem for many people. The tragedy in this story is that Beina, who lost her parents as a teenager, winds up losing her foster-parents because she refuses to divorce her homosexual husband, Baowen.

I find it ironic that Beina's foster father, Cheng, was concerned at the beginning of the 
marriage that Baowen would find female companionship outside of their marriage because Beina was not very attractive or outgoing but wound up giving Beina the ultimatum to divorce Baowen or she would be disowned once it was discovered that Baowen was homosexual and it was not a disease. Cheng was weary of the marriage at the start, "How could he be serious about his offer?" (401). As Sarah Duckworth noted, "Because Cheng has built his life on appearances, he sees Beina's marriage as related to his own standing in society" (3). When Beina tells Cheng she is going to wait for Baowan, his response was to disown her. "Well, it's impossible for me to have a criminal for a sonin-law. I've been humiliated enough. If you want to wait for him, don't come see me again." (413)

Baowan and his friends were not disturbing anyone. They were not flaunting their homosexuality in public or attempting to gain attention in any way. They were simply looking for a place to be themselves and created a club. The police, fearful they might be a violent group, secretly joined the club, Men's World. One club member commented "Now I feel alive! Only in here can I stop living in hypocrisy." (403). Even though they were not violent, when the club grew to approximately 30 members, the police stepped in and arrested them for being homosexuals. At the time the government treated homosexuality as "hooliganism" (403) and thought it "a crime and punishable by prison time or by therapy" (Webmaster 1). Those found guilty were sentenced to jail time, rehab, or punished and released depending on the level of guilt. Since most of the members were sent to hospitals for treatment, Justin Rech, suggests "It is inferred that it is better to be considered to have a mental disorder than to actually be gay" (1).

Instead of jail, Baowen was sentenced to rehab to try to cure him of his homosexuality as long as Cheng's factory would pay the hospital bills. Some of the treatments to try and cure this disease were taking an electric bath, having electric cuffs around their limbs, or electric rods on their bodies. Baowen had even tried some cures himself when he first acknowledged his preference for men. He told Cheng "I took lots of herbs and boluses, and even ate baked scorpions, lizards, and toads" (404). When Cheng and Beina visited Baowen, he poured them malted milk because he was "unsure whether homosexuality was communicable" (410), Cheng refused it. Cheng was shocked when Dr. Mai advised him that "Homosexuality isn't an illness, so how can it have a cure? The problem with all of these is that homosexuality is not curable" (411). As posted by Ocean Lu, "Homosexuality, as a human nature, shouldn't be regarded as a physical or mental disease. It is just a sexual preference and it has nothing to do with socialism or capitalism" (2).

Some of the factory workers gossiped that homosexuality was a part of China's history, for example, the Beijing opera actors because women were not allowed, some emperors during the Han Dynasty had kept male lovers, and one thought that it "was an upper-class thing" (405). If it was acceptable under these circumstances, why couldn't it be accepted all the time?

Without a cure, what can be done? Teach tolerance and acceptance. Beina knew she could not change Baowen even though she did not understand what was really happening. She chose to accept him. To allow the marriage to work as a cover for Baowen and give her the status of have having a husband. Baowen's mother would never need to know.

Regardless what the prejudice is, we need to learn to accept each other as we are. Can't we agree to disagree when we don't see eye to eye? Why do we insist that there is only one right? We need to understand we are all unique, created differently. We were not made identically for a reason. We may never understand this reason but maybe we are not meant too. Understanding and accepting this would be our first step to stopping prejudice and accepting each other as we are.

We may think we know who we are but how can we? We grow up believing what we are taught. We don't know if our parents are hiding anything from us in order to protect us, like Armand's mother in "Désirée's Baby" who wrote "I thank God for having so arranged our lives that our dear Armand will never know that his mother, who adores him, belongs to the race that is cursed with the brand of slavery" (245). We must be taught tolerance and acceptance.

Everyone should have equal opportunities. There should not be discrimination because of 
who you are, who you are related to, or what you believe in. In "The Bridegroom" it was said that "a criminal's wife was not supposed to have the same employment opportunities as others" (413). A family should not be judged by the actions of one person. Until prejudiced is stopped, guilt by association will also continue to be a problem.

One person cannot change the world. One person can start it. Change can work like a domino effect, one person can change another person who changes another person, and so on. We must all work together if we are ever going to end prejudice and see Peace on Earth.

\section{Works Cited}

Chopin, Kate. "Désirée’s Baby." Elizabeth McMahan, et al. 241-245.

DizzyRae. "Literary Analysis of Désirée’s Baby." Teen Ink. Web. October 23, 2011.

Dr. Mark. "Désirée's Baby-Kate Chopin-A Noble Theme.” American Literature, Realism. March 24, 2011. Web. October 23, 2011.

Ducksworth, Sarah Smith. "The Bridegroom." Masterplots II: Short Story Series, Revised Ed. (2004): 1-3. MagillOnLiterature Plus. EBSCO. Web 23 Oct. 2011.

Jin, Ha. "The Bridegroom." Elizabeth McMahan, et al.. 400-413.

Lu, Ocean. "Homosexuality in the Bridegroom." Blog. Oct 23, 2011.

McMahan, Elizabeth, et al. Literature and the Writing Process. $9^{\text {th }}$ ed. Indianapolis: Longman, 2011. Print.

Okita, Dwight. "In Response to Executive Order 9066 All Americans of Japanese Descent Must Report to Relocation Centers." Elizabeth McMahan, et al. 695-696.

Positivelydifferent. "Discrimination Through Time.” Blog. Oct. 23, 2011

Rech, Justin. "The disdain and curiosity of homosexuality in "The Bridegroom"." EssayPedia.com. Oct 23, 2011.

Rosenblum, Joseph. “Désirée’s Baby.” Masterplots II: Short Story Series, Revised Ed. (2004): 1-2. MagillOnLiterature Plus. EBSCO. Web 23 Oct. 2011.

Webmaster. "Essay on The Bridegroom.” Blog. Oct. 23, 2011. 